SF 258

. $\mathrm{P}_{5} \mathrm{~A}_{4}$ 
Milk and Its Distribution in Philadelphia

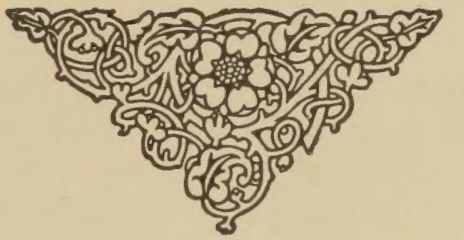

ISSUED BY

THE EDUCATIONAL COMMITTEE OF THE

PHILADELPHIA CHAMBER OF COMMERCE 


\section{PRESENTED TO THE \\ SCHOOLS OF PHILADELPHIA \\ BY THE \\ PHILADELPHIA MILK EXCHANGE}

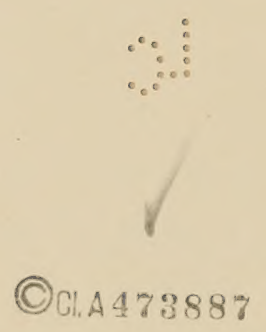

Educational Pamphlet No. 8, issued by the Educational Committee of the Philadelphia Chamber of Commerce.

Copyright, 1917, Phlladelphia Chamber of Commerce.

$$
\text { OCT }-81917
$$




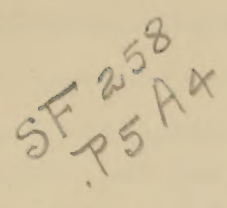

\title{
Milk and Its Distribution in Philadelphia
}

\author{
By THOMAS B. HARBISON
}

$\mathrm{W}$

ITH the growth of the eity the distribution of milk has become a community industry. In the early days of Philadelphia's life, practically every family had its own cow, so that the problem of securing milk was a family matter, but with the growth of populous communities and the abandonment of many farms, the production and distribution of milk came to be a matter of community interest.

In the first place, one man owning one farm and several cows, distributed the milk to his neighbors. Gradually the production of several farms was needed to meet the demand. Then instead of delivering milk to each household, the distributor having placed cans of milk and an attendant at certain street corners for an hour or two each day, dipped the milk into a vessel furnished by the purchaser.

This method was succeeded by one in which the distributor, in a wagon, rang a bell to announce his arrival-upon which the housewife came to the wagon with a vessel to secure the daily needs. No attention was given to the time of delivery, for the householder accepted the needed supply at the convenience of the distributor.

In turn this plan was succeeded by the handling of milk by the grocery store to accommodate the customers whose supply had become exhausted by unexpected demands on the family stock. Gradually the stores became more and more a means of distributing the daily supply. The distributor ceased the "bell ringing" plan and instituted the method of calling at the door of each person considered to be a daily customer.

The daily milk supply of Philadelphia is over five hundred thousand quarts. In 1916 the amount of milk received was 191,387,865 quarts. This was transported by the Pennsylvania, the Philadelphia \& Reading, and the Baltimore \& Ohio Railroad Companies; by the Adams, the Wells-Fargo, and the American Express Companies; by the Philadelphia Rapid Transit and the West Chester Trolley System; and by auto trucks and wagons. The milk used in Philadelphia is produced in the States of Pennsylvania, New Jersey, New York, Delaware and Maryland. Most of this supply is transported from within a hundred miles of Philadelphia; while the most distant points are near Buffalo and Rochester, New York. 
The transportation of milk originally was for short distances. The rates established were inharmonious and inconsistent, and the traffic received little attention. No attempt was made to establish an icing service until 1910, when the Philadelphia Board of Health took active measures to insure that milk and cream should arrive at a temperature

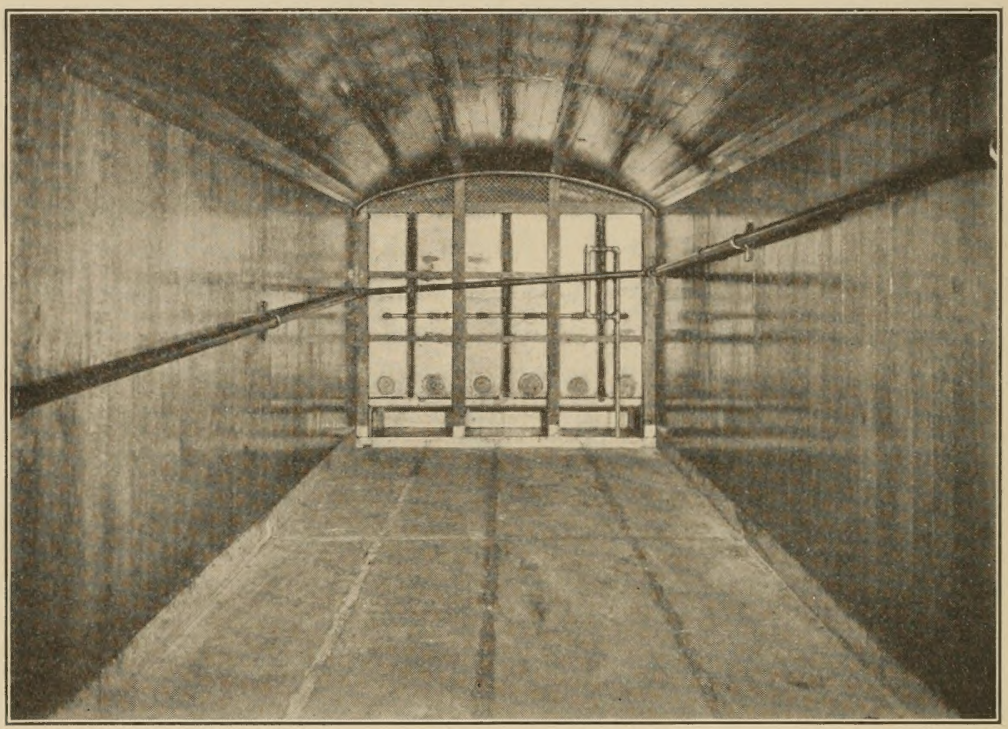

Fig. 1. Interior of milk car cooled by cold pure air

not exceeding 60 degrees Fahrenheit. In the spring of 1911, the steam roads initiated the practice of icing milk and cream, while in 1912, icing became the general practice by all carriers in the transportation of milk from the points of production to their terminals. (See Fig. 1.)

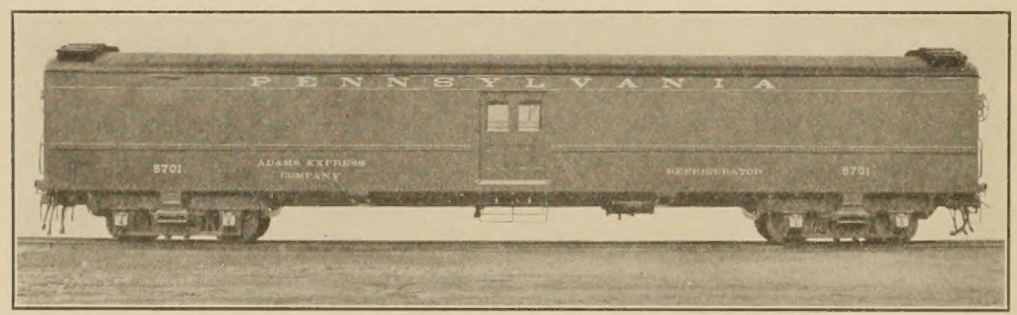

Fig. 2. Penna, R. R. Co. new pattern Milk Car

The milk and cream traffic hạs grown to such proportions as to require the establishment of special trains for its transportation. (See Fig. 2.) The service is arranged to gratify the needs of the business; to 
furnish facilities for the reception of milk in the country at the most satisfactory hours of the day, and to secure its delivery in the city at the hours most advantageous for its subsequent distribution to the community. In the United States there are twenty-two million dairy cows, producing annually milk and milk products totalling a value of one and a half billion dollars, which value is greater than that of the wheat crop.

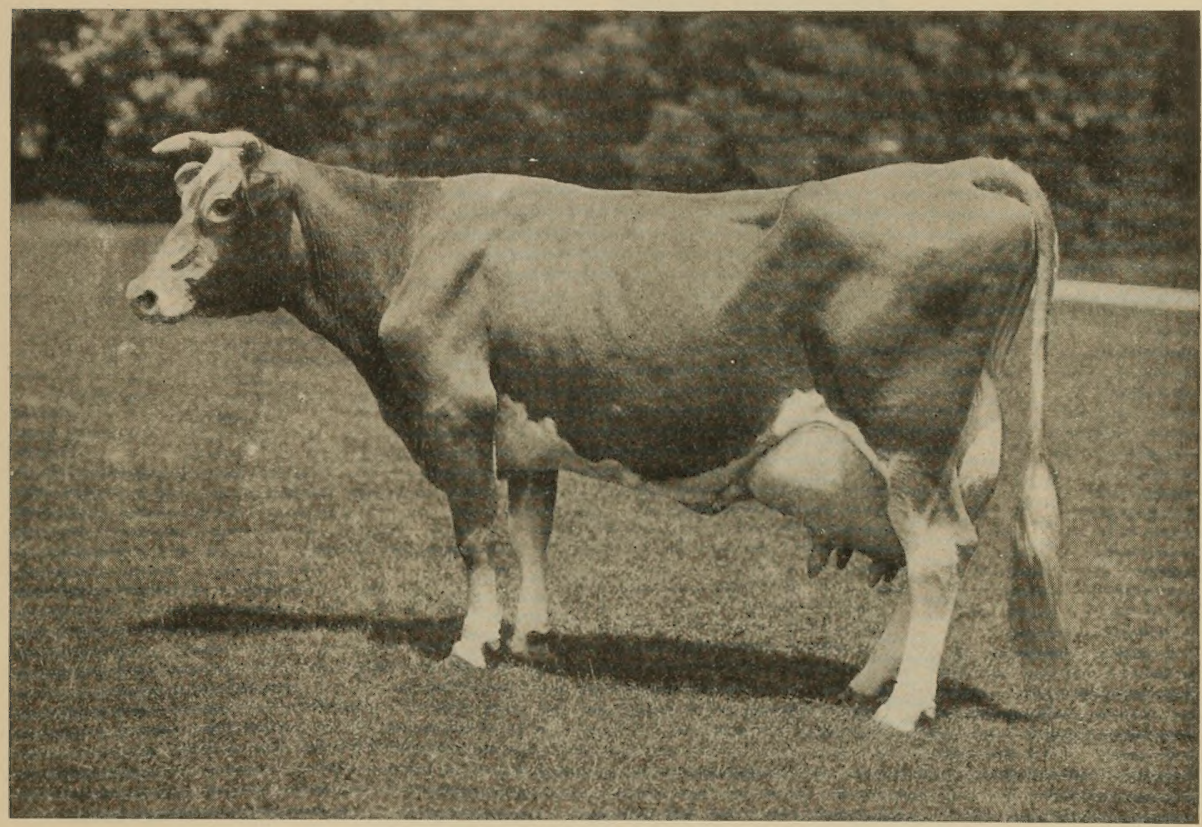

Fig. 3. Cow well cared for and contented

The dairy cow is a machine which manufactures or converts feed into milk. The cow's heart pumps blood to all parts of the body, supplying large amounts to the udder, which is similar in composition to a large sponge and in shape to an inverted bunch of grapes. (See Fig. 3.) The udder cells transform the blood into milk. By means of hand pressure or mechanical suction the milk is drawn from the udder to the milk pail. All milk when drawn from the cow is composed of fat, milk sugar, casein, albumen, ash and water.

The cream being lighter is separated from the milk either by gravity or by centrifugal method. The old method of gravity skimming was not dependable or efficient. By the centrifugal method or separator, the bowl is run at a speed of 6,000 to 8,000 revolutions a minute, thus discharging the separated cream and skim milk from separate spouts. 


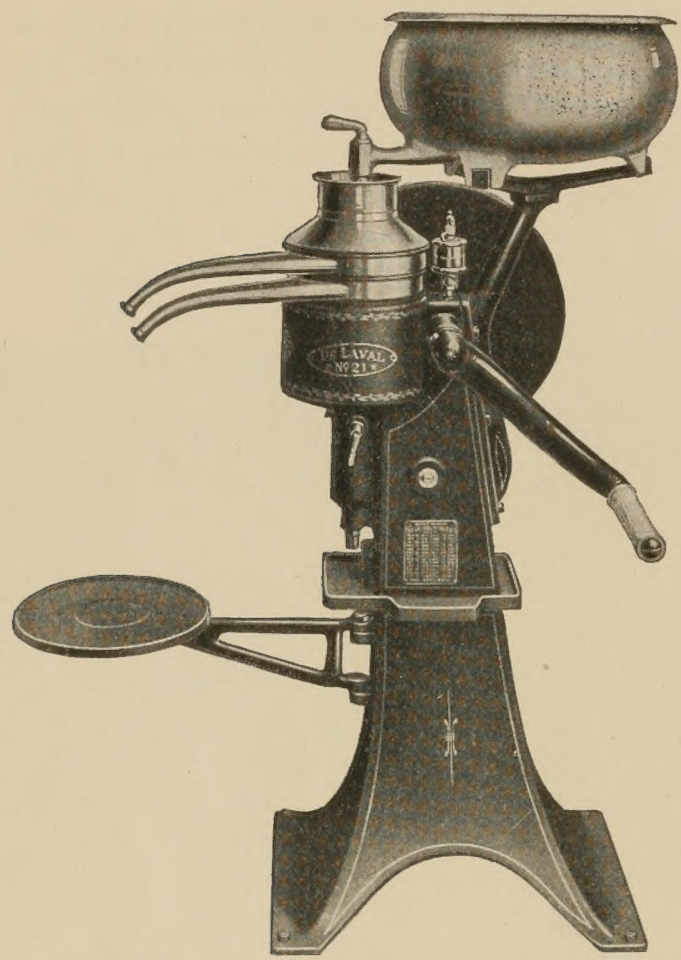

Fig. 4. Making cream by centrifugal method or separator

The butter fat content of the cream may be varied from 20 to 60 per cent. by the mere turning in and out of a regulating screw. Cream is used for commercial cream, ice cream and butter making. (See Fig. 4.)

Ice cream is a food of high value. The combination of sugar, butter fat (cream) with flavors and frozen, is increasing in use.

Butter is made from cream. The churning of cream causes the butter fat to adhere together in little masses which are finally bulky enough to be removed from the liquid in which they float. In the process of butter-making the cream is allowed to undergo a process of ripening to develop the desirable flavor of the butter.

Prepared culture is used as a starter for inoculating the cream to be ripened for churning, after the cream has been heated to about 155-160 degrees. The cream of ten to twelve quarts of milk is required to make a pound of butter.

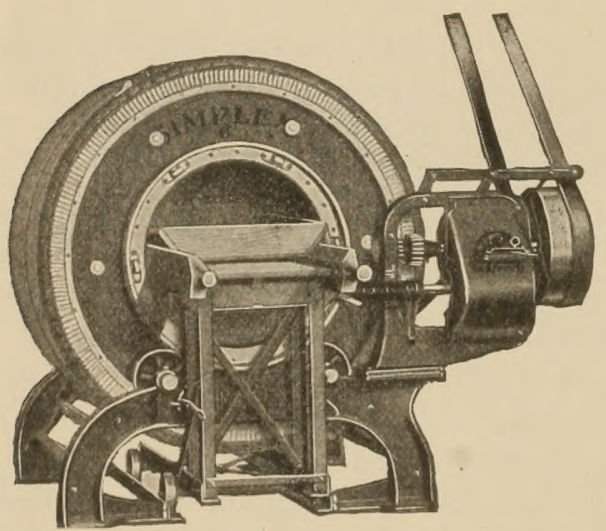

Fig. 5 .Churn for making butter and buttermilk

Buttermilk is the liquid remaining after the butter fat has been separated from the cream by churning. (See Fig. 5.) It is a beverage consisting largely of water, sugar, casein, ash and lactic acid. Science has awarded to buttermilk a high place as an article of diet, because it is a preventative of stomach disorders and intestinal troubles.

Skim milk is of high food value and should be more generally used by the consumer. 
Milk is also manufactured into condensed milk, evaporated milk, milk powder, cheese and smear-case, all of which are sold extensively in our markets.

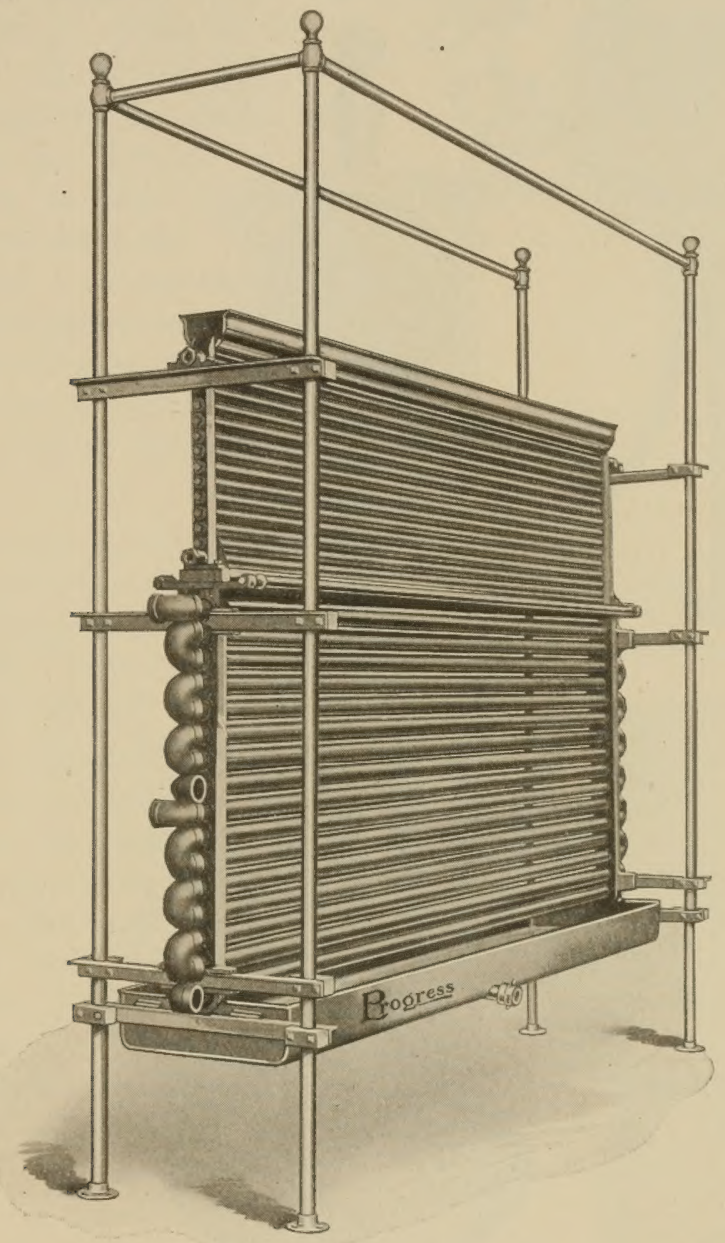

Fig. 6. Cooling milk from 145 degrees to 40 degrees, in less than a minute

It is now generally accepted that it is the duty of every community to have its milk supply properly safeguarded. GOOD, CLEAN milk and cream are essential to the public health. (See Fig. 6.) Undue emphasis has been laid upon the inspection of equipment and methods, while inspection of the product has been more or less neglected. (See Fig. \%.) In Pennsylvania there are no laws specifying standards for grades under which milk and eream are sold. The sale of milk and cream by grades is catering to the demands of the public, but in no way gives the protection that could be received if standards were established by law or regulations made by the Board of Health. Inspection has 
been carried to extremes, with little good results. The sanitary character of milk is now determined by the bacteria count. Bacteria are minute organisms of vegetable origin which multiply rapidly in milk

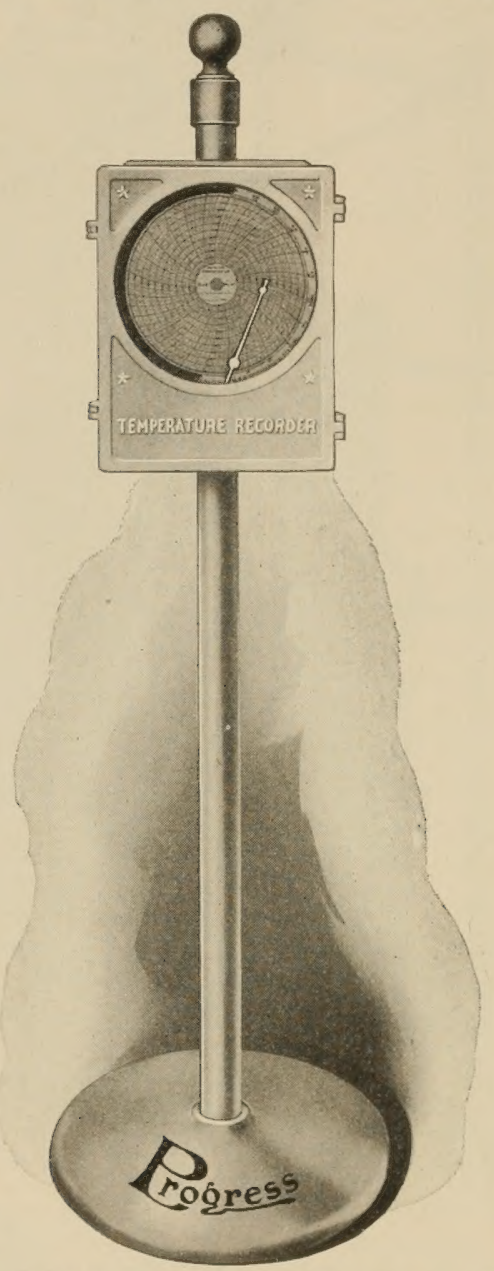

Fig. 7. Diagram recording time and temperature of milk

and cream when the temperature of milk or cream is 60 degrees or higher. Bacteria grow more rapidly under conditions of moisture or heat. To test for bacteria, samples of milk and of cream are diluted with sterile water in the proportion of ninety-nine parts water to one part of milk. To this is added agar, a transparent gelatinous substance containing beef tea and other food to make the bacteria grow. The test plate is then placed in the incubator at the temperature of the human body. At the end of 48 hours the individual bacteria have multiplied into colonies, which may be easily counted, so as to ascertain the number of bacteria close enough to classify the milk. 
The butter fat content of milk or cream is determined by a machine known as the Babcock Tester. A sample of milk or cream is mixed with an equal amount of sulphuric acid, which dissolves the casein and sets the butter fat free. This mixture is placed in the tester and whirled for five minutes. Water is then added and a subsequent whirling in the tester forces the butter fat into the graduated neck of the testing bottle, where the percentage of butter fat can readily be measured. (See Fig. 8.)

There are various requirements in the cities and States in regard to the legal minimum standard of butter fat for milk. It is desirable that each container should specify the butter fat of the milk or cream. Many producers of milk are selling on the butter fat basis, because of the great variations in the composition of milk. The usual variation is from two and eight-tenths per cent. butter fat to five per cent. This variation is caused by the development of the different breeds of cows, such as Ayrshires, Jerseys, Holsteins, Guernseys, etc. The kind or amount of feed may increase the amount of milk, but it will not materially affect the butter fat content, which is determined by the breed of the cow.

The handling of milk has become more sanitary with the introduction of machinery for clarifying, pasteurizing and bottling. Clarifying means centrifugally cleansing milk of the udder waste, foreign and impure matter that it may contain, without

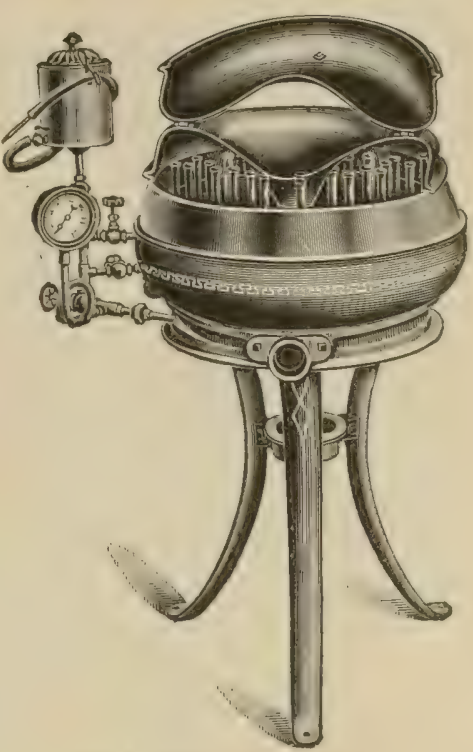

Fig. 8. Testing for butter fat

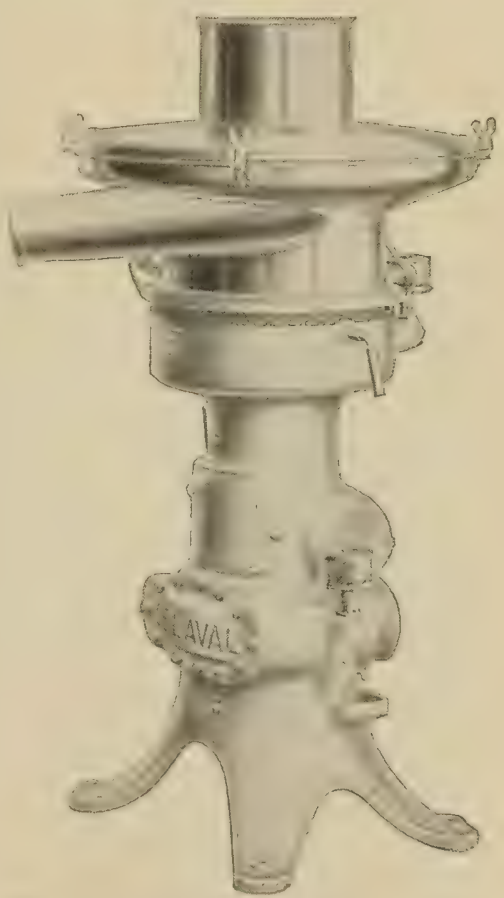

Fig. 9. Clarifier cleansing milk of the udder waste and impure matter affecting its normal constitnents. (See Fig. 9.) The dairy cow herself 
contributes a peculiar form of contamination. There is a constant shedding of waste tissue from the lining of the udder. In some form this udder waste is found in practically every dairy herd. Udder waste, pus and bacteria are removed when milk is passed through a clarifier, thus rendering milk much more sanitary.

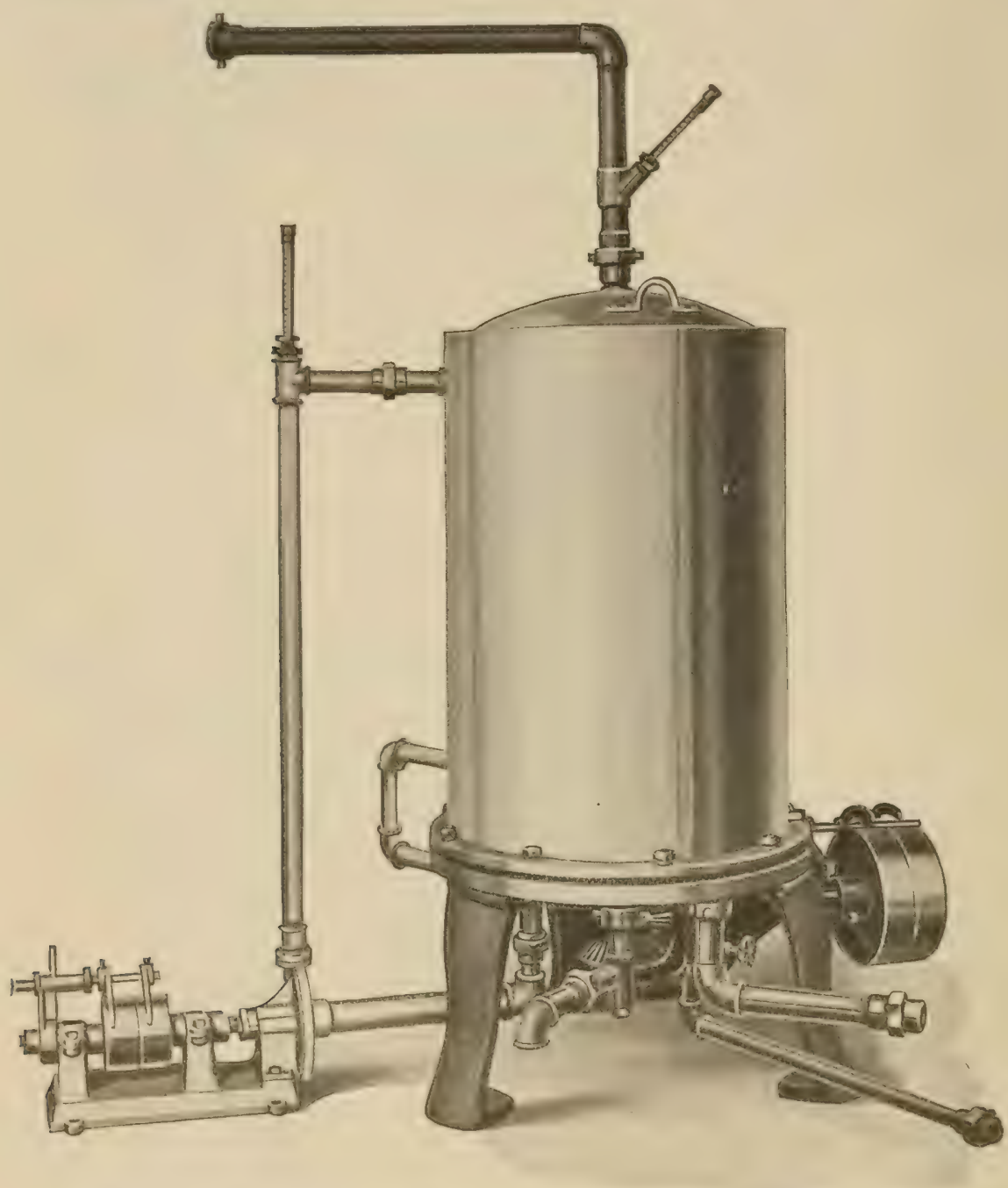

Fig. 10. Hot water circulates through the inside while the milk passes around the outside drum of the German silver pasteurizer

Pasteurizing consists of heating milk to a certain temperature for such a length of time as will destroy the most bacteria; 145 degrees F. for thirty minutes is recommented hy the best serentifie anthorities ats a guarantee that the bacteria of disease will be destroyed. (Sec Figs. 10 


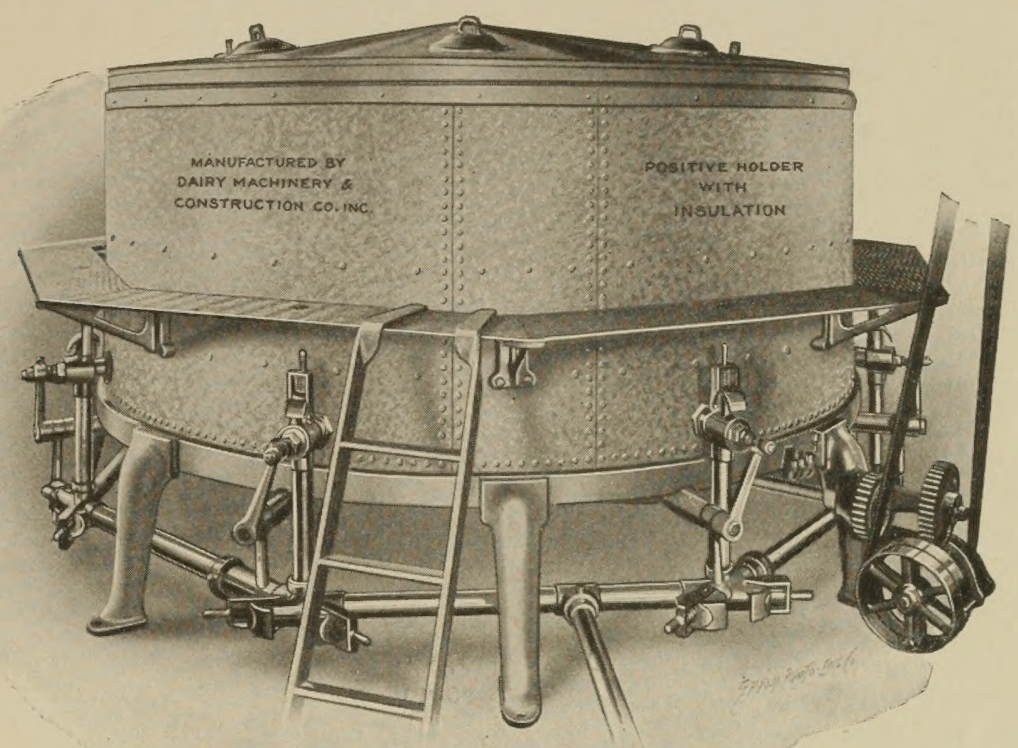

Fig. 11. Milk at 145 degrees held at that temperature for 30 minutes, automatically timed and operated

and 11.) The leading milk authorities now believe that even the best raw milk is unsafe and should be pasteurized. To show the value of pasteurization, experiments have been made. In New York City, 18,000 babies were fed pasteurized milk for three years. Records show that these babies gained in weight, kept well in every way, while the death rate in that city, during this period, w as reduced from 125 per thousand to 94 p e r thousand births.

Bottling is now done by machinery, a whole case of bottles being

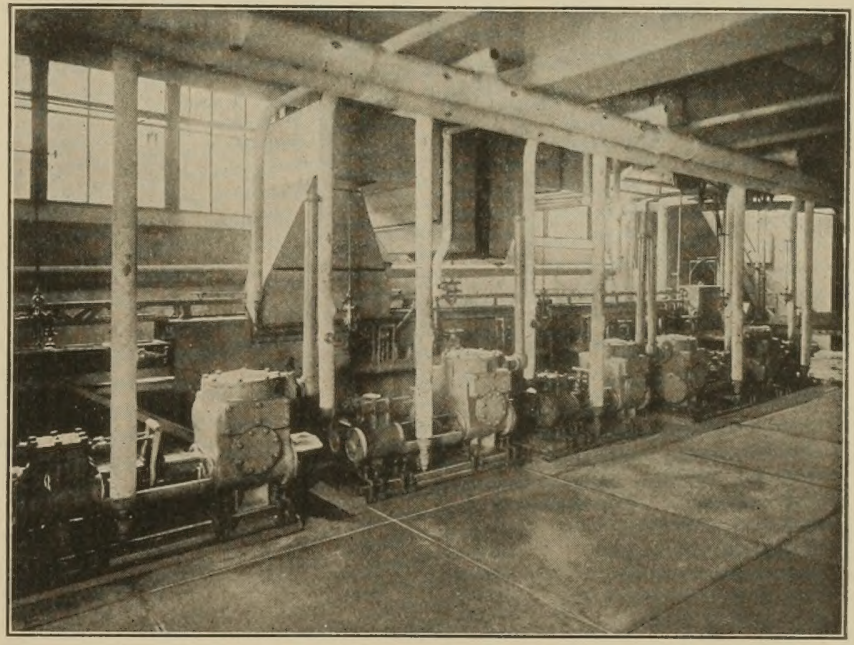
filled with a single operation. Capping also is done by machinery. 
Powerful washing machines are used in which the milk bottles are washed and completely sterilized. Many of these machines consist of a number of large tanks with powerful steam pumps, through which the bottles and boxes pass in succession. Each bottle is washed five to fifteen times with water at thirty pounds pressure. As the inverted bottles and boxes pass through the machine, the water is changed in each tank, starting at a temperature of 90 degrees and proceeding to sterilization at 212 degrees. (See Fig. 12.)

The Division of Milk Inspection of the Philadelphia Board of Health was first organized in 1889, and at present consists of the Chief Inspector and sixteen assistants. The city is divided into three farm districts and thirteen local districts. Under the Act of April 29, 1909, amended June 9, 1911, all milk dealers are licensed. The Board of Health may revoke any license on failure to comply with the rules and regulations governing the sale of milk.

The rules and regulations prohibit the sale by the process of "dipping," except in stores approved by the Board of Health, and no milk shall be bottled or stored in any room used for domestic purposes, or in any stable.

At the present time there are in force, 5,428 licensed milk dealers, distributed as follows: 311 milk dealers; 73 milk dealers driving into Philadelphia; 232 producers supplying milk in Philadelphia; 4,812 grocery stores, hotels and restaurants.

There are 130 pasteurizing plants, of which 112 plants daily pasteurize from 750 quarts to 5,000 quarts each, while the 18 plants remaining, each pasteurize from 7,500 to 50,000 quarts daily.

\section{EDUCATIONAL PAMPHLETS ISSUED BY THE}

\section{PHILADELPHIA CHAMBER OF COMMERCE}

PURPOSE-To make Philadelphia's life, industry, history, and government known, understood and appreciated by all its citizens.

No. 1. Thrift-a short text-book

No. 2. The Trust Companies of Philadelphia

No. 3. The Rug and Carpet Industry of Philadelphia

No. 4. The Locomotive Industry in Philadelphia

No. 5. Truck Farming in Philadelphia County

No. 6. Candy Making in Philadelphia

No. 7. The Leather and Glazed Kid Industry in Philadelphia

No. 8. Milk and Its Distribution in Philadelphia 
SF 258

$\mathrm{P}_{5} \mathrm{~A}_{4}$ 


\section{LIBRARY OF CONGRESS}

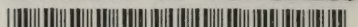

00008960781

Hollinger Corp.

pH 8.5 